\title{
Isolation, Structure Elucidation and In Silico Prediction of Potential Drug-Like Flavonoids from Onosma chitralicum Targeted towards Functionally Important Proteins of Drug-Resistant Bad Bugs
}

\author{
Shakeel Ahmad Khan ${ }^{1}$, Shafi Ullah Khan ${ }^{2,3}{ }^{\mathbb{D}}$, Fozia ${ }^{4}$, Najeeb Ullah ${ }^{5}$, Mohibullah Shah ${ }^{5}$ (D), Riaz Ullah ${ }^{6, *(D)}$, \\ Ijaz Ahmad ${ }^{1, *}$ and Amal Alotaibi ${ }^{7, *}$
}

check for updates

Citation: Khan, S.A.; Khan, S.U.; Fozia; Ullah, N.; Shah, M.; Ullah, R.; Ahmad, I.; Alotaibi, A. Isolation, Structure Elucidation and In Silico Prediction of Potential Drug-Like Flavonoids from Onosma chitralicum Targeted towards Functionally Important Proteins of Drug-Resistant Bad Bugs. Molecules 2021, 26, 2048. https://doi.org/10.3390/ molecules 26072048

Received: 22 February 2021

Accepted: 30 March 2021

Published: 2 April 2021

Publisher's Note: MDPI stays neutral with regard to jurisdictional claims in published maps and institutional affiliations.

Copyright: (c) 2021 by the authors. Licensee MDPI, Basel, Switzerland. This article is an open access article distributed under the terms and conditions of the Creative Commons Attribution (CC BY) license (https:// creativecommons.org/licenses/by/ $4.0 /)$.
1 Department of Chemistry, Kohat University of Science \& Technology, Kohat 26000, Pakistan; shakeelchemist@gmail.com

2 School of Pharmacy, Monash University, Bandar Sunway, Subang Jaya 47500, Malaysia; shafiullahpharmd@gmail.com

3 Department of Pharmacy, Abasyn University, Ring Road, Peshawar 25120, Pakistan

4 Biochemistry Department, KMU Institute of Medical Sciences, Kohat 26000, Pakistan; drfoziazeb@yahoo.com

5 Department of Biochemistry, Bahauddin Zakariya University, Multan 60800, Pakistan; najeebkhattak@bzu.edu.pk (N.U.); mohib@bzu.edu.pk (M.S.)

6 Department of Pharmacognosy, College of Pharmacy, King Saud University Riyadh Saudi Arabia, Riyadh 11495, Saudi Arabia

7 Basic Science Department, College of Medicine, Princess Nourah bint Abdulrahman University, Riyadh 11671, Saudi Arabia

* Correspondence: rullah@ksu.edu.sa (R.U.); drijaz_chem@yahoo.com (I.A.); amaalotaibi@pnu.edu.sa (A.A.)

Abstract: Admittedly, the disastrous emergence of drug resistance in prokaryotic and eukaryotic human pathogens has created an urgent need to develop novel chemotherapeutic agents. Onosma chitralicum is a source of traditional medicine with cooling, laxative, and anthelmintic effects. The objective of the current research was to analyze the biological potential of Onosma chitralicum, and to isolate and characterize the chemical constituents of the plant. The crude extracts of the plant prepared with different solvents, such as aqueous, hexane, chloroform, ethyl acetate, and butanol, were subjected to antimicrobial activities. Results corroborate that crude (methanol), EtoAc, and n$\mathrm{C}_{6} \mathrm{H}_{14}$ fractions were more active against bacterial strains. Among these fractions, the EtoAc fraction was found more potent. The EtoAc fraction was the most active against the selected microbes, which was subjected to successive column chromatography, and the resultant compounds 1 to 7 were isolated. Different techniques, such as UV, IR, and NMR, were used to characterize the structures of the isolated compounds 1-7. All the isolated pure compounds (1-7) were tested for their antimicrobial potential. Compounds 1 (4',8-dimethoxy-7-hydroxyisoflavone), 6 (5,3',3-trihydroxy7,4'-dimethoxyflavanone), and 7 (5',7,8-trihydroxy-6,3', $4^{\prime}$-trimethoxyflavanone) were found to be more active against Staphylococcus aureus and Salmonella Typhi. Compound $\mathbf{1}$ inhibited S. typhi and S. aureus to $10 \pm 0.21 \mathrm{~mm}$ and $10 \pm 0.45 \mathrm{~mm}$, whereas compound 6 showed inhibition to $10 \pm 0.77 \mathrm{~mm}$ and $9 \pm 0.20 \mathrm{~mm}$, respectively. Compound 7 inhibited S. aureus to $6 \pm 0.36 \mathrm{~mm}$. Compounds 6 and 7 showed significant antibacterial potential, and the structure-activity relationship also justifies their binding to the bacterial enzymes, i.e., beta-hydroxyacyl dehydratase (HadAB complex) and tyrosyl-tRNA synthetase. Both bacterial enzymes are potential drug targets. Further, the isolated compounds were found to be active against the tested fungal strains. Whereas docking identified compound 7, the best binder to the lanosterol $14 \alpha$-demethylase (an essential fungal cell membrane synthesizing enzyme), reported as an antifungal fluconazole binding enzyme. Based on our isolationlinked preliminary structure-activity relationship (SAR) data, we conclude that $O$. chitralicum can be a good source of natural compounds for drug development against some potential enzyme targets.

Keywords: Onosma chitralicum; flavonoids; antimicrobial activities; SAR; beta-hydroxyacyl dehydratase 


\section{Introduction}

Microorganisms, including viruses, bacteria, and others, are potentially harmful to other living organisms, mainly humans. Bacteria largely become resistant to antibiotics, throughout the world, as examined in many hospital studies [1]. For this reason, the discovery of new and modified broad-spectrum antibiotics is very important and essential to overcome diseases. There are many sources of antimicrobials, but plants are rich sources of them. Plants are used in various countries; however, their medicinal use is central in many powerful and effective medicines [2]. Herbs are used to treat different diseases due to their efficacy and low cost, however, doctors often hesitate to recommend them because of a lack of knowledge about herbs, concerns about liability, product safety, and the existence of harmful ingredients [3]. Many bacterial strains acquired resistance against various antibiotics due to changes in their structures, mutations in their genes, and most importantly, due to excessive unselective intake of antibiotics for the treatment of various infectious diseases. All of these modifications result in the usefulness of most antibiotics and generate a renewed interest in herbal medicines [4].

The name onosma derived from "Osma" (Latin word) means smelly, and was used, for the first time, by Linnaeus in modern botanical classification. About 150 types of known species are included in this genus Onosma (Boraginaceae), and distributed in Asia, including China (39 species), Turkey (95 species), Pakistan (eight species), and others (eight species) [5]. A literature survey revealed that very little phytochemical work has been carried out on the genus Onosma, and only some flavonoids [6], naphthoquinones [7], alkaloids [8], and phenolic compounds [9] have so far been reported. Onosma chitralicum is a well-known medicinal plant belonging to the genus Onosma. Onosma chitralicum plant is mostly distributed in tropical and temperate regions, especially the Mediterranean regions. The Onosma chitralicum plant is a perennial herb, having multi-branched stems. Leaves and stems are densely hairy, with extensively growing hair. The flowers of this plant are nearly actinomorphic and bisexual [5].

Onosma chitralicum plants have different biological properties, including laxative, cooling, and anthelmintic effects among others. This plant also shows effective treatment in derangements of blood, the diseases of the eye, abdominal pain, bronchitis, wound, fever, and pile. In Pakistan, this plant is locally used by the people of Chitral to treat the diseases of the eye, as well as wounds [10].

Although Onosma chitralicum is famous for its medicinal properties, it has not been investigated for this purpose. The objective of this study was to evaluate the biological activities of crude extract, as well as different solvents, soluble fractions of the Onosma chitralicum (medicinal plant). The most active fraction was then used for the isolation of chemical constituents and biological activities of those isolated compounds were then performed.

In this article, we report the antibacterial and antifungal activities of the crude extract, solvents soluble fractions, and new source compounds (1-7) isolated for the first time from Onosma chitralicum, but reported already from different sources as referenced in the Materials and Methods section, which were individualized by various techniques named one-dimensional (1D) and two-dimensional (2D) NMR.

\section{Results and Discussion}

Onosma chitralicum plant crude extract, fractions of different solvents and compounds 1 to 7 (shown in Figure 1), underwent antimicrobial evaluation to study their biological importance. Different solvents, either polar or non-polar (methanol, $n$-hexane, chloroform, ethyl acetate, $n$-butanol and aqueous) soluble fractions, were active against the tested microbial specimen. For antibacterial assays, five bacterial species, i.e., Escherichia coli, Staphylococcus aureus, Pseudomonas aeruginosa, Bacillus subtilis, Salmonella typhi; and for antifungal assays, five fungal species, i.e., Aspergillus flavus, Aspergillus fumigates, Aspergillus niger, Fusarium solani, Candida glabrata strains, were used. 
<smiles>COc1ccc(-c2coc3c(OC)c(O)ccc3c2=O)cc1</smiles>

4', 8-dimethoxy-7-hydroxyisoflavone (1)<smiles>COc1ccc2c(c1)OC(c1ccccc1)C(O)C2=O</smiles>

2, 3-dihydro-3-hydroxy-7- methoxyflavone (3)<smiles>COc1ccc(-c2coc3cc(OC)ccc3c2=O)cc1</smiles>

7, 4'-dimethoxy-isoflavone (5)<smiles>COc1cc2c(=O)c(-c3cc(OC)c(OC)c(OC)c3)coc2c(O)c1O</smiles>

5, 8, 7-trihydroxy-3, 4, 6- trimethoxyisoflavanone (7)<smiles>COc1cc(O)c2c(c1)OC(c1ccccc1)C(O)C2=O</smiles>

2, 3-dihydro-3, 5 dihydroxy-7- methoxyflovone (2)<smiles>COc1cc(C2=COC3C=C(O)C=CC3C2=O)ccc1O</smiles>

7, 4'--dihydroxy-3'-methoxyisoflavone (4)<smiles>COc1ccc(C2Oc3cc(OC(C)=O)cc(C)c3C(=O)C2O)cc1O</smiles>

5, 3', 3-trihydroxy-7, 4'-dimethoxyflavanone (6)

Figure 1. Structures of compounds (1-7).

\subsection{Antibacterial Activity of Fractions}

The antibacterial activities of Onosma chitralicum against five bacterial strains (shown in Table 1) were found active against all. The fraction of ethyl acetate (EtoAc), crude, and hexane $\left(n-\mathrm{C}_{6} \mathrm{H}_{14}\right)$ fraction of Onosma chitralicum revealed a more potent activity than chloroform $\left(\mathrm{CHCl}_{3}\right), n$-butanol $(\mathrm{BuOH})$, and aqueous fractions against various strains. The activity of ethyl acetate fraction $(16.0 \mathrm{~mm})$ was shown against $S$. typhi, while against $E$. coli and $S$. aureus with a $12 \mathrm{~mm}$ inhibition zone for each. The activity of methanol/crude fraction against $S$. typhi strain $(17 \mathrm{~mm}), E$. coli strain $(13 \mathrm{~mm})$, and the $S$. aureus strain $(13 \mathrm{~mm})$ are shown in Table 1.

Table 1. Antibacterial activities showing zone of inhibition $(\mathrm{mm}) \pm$ standard error mean of various fractions $(15 \mathrm{mg} / \mathrm{mL})$ of Onosma chitralicum.

\begin{tabular}{ccccccc}
\hline S.\# & Fractions & E. coli & P. aeruginosa & S. aureus & S. typhi & B. subtilis \\
\hline 1. & Crude & $13.0 \pm 0.46$ & $8.0 \pm 0.23$ & $13.0 \pm 0.44$ & $17.0 \pm 0.52$ & $12.0 \pm 0.39$ \\
2. & $n$-hexane $\left(\mathrm{C}_{6} \mathrm{H}_{14}\right)$ & $11.0 \pm 0.61$ & $2.0 \pm 0.30$ & $8.0 \pm 0.32$ & $7.0 \pm 0.32$ & $10.0 \pm 0.67$ \\
3. & Chloroform $\left(\mathrm{CHCl}_{3}\right)$ & $4.0 \pm 0.42$ & $6.0 \pm 0.40$ & $6.0 \pm 0.46$ & $3.0 \pm 0.22$ & $2.0 \pm 0.25$ \\
4. & Ethyl acetate (EtoAc) & $12.0 \pm 0.32$ & $3.0 \pm 0.33$ & $12.0 \pm 0.21$ & $16.0 \pm 0.47$ & $11.0 \pm 0.41$ \\
5. & n-butanol (BuOH) & $3.0 \pm 0.22$ & $4.0 \pm 0.32$ & $5.0 \pm 0.53$ & $3.0 \pm 0.14$ & $2.0 \pm 0.12$ \\
6. & Aqueous & $3.0 \pm 0.23$ & $1.0 \pm 0.15$ & $3.0 \pm 0.26$ & $5.0 \pm 0.28$ & $2.0 \pm 0.16$ \\
7. & Doxycycline (standard) & $16.0 \pm 0.12$ & $10.9 \pm 0.15$ & $20.0 \pm 0.26$ & $24.0 \pm 0.13$ & $22.0 \pm 0.29$ \\
\hline
\end{tabular}




\subsection{Antifungal Activity of Fractions}

The antifungal activities of $O$. chitralicum were subjected to five fungal strains and the results are given in (Table 2). In the antifungal assay, ethyl acetate and methanol/crude fractions of O. chitralicum were not only excellent, but also active against all fungal strains as compared to $\mathrm{CHCl}_{3}, n$-hexane, $\mathrm{BuOH}$ and, aqueous fractions. Methanolic fraction's activity against Aspergillus flavus strain was $65 \mathrm{~mm}$, Fusarium solani was $63 \mathrm{~mm}$, and Aspergillus niger was $58 \mathrm{~mm}$, whereas the ethyl acetate fraction's activity against, $A$. flavus strain was $60 \mathrm{~mm}$; details are elaborated in Table 2.

Table 2. Antifungal activities showing zone of inhibition $(\mathrm{mm}) \pm$ standard error mean of various fractions $(15 \mathrm{mg} / \mathrm{mL})$ of Onosma chitralicum.

\begin{tabular}{ccccccc}
\hline S.\# & Fractions & A. flavus & F. Solani & $\begin{array}{c}\text { Aspergillus } \\
\text { fumigatus }\end{array}$ & A. niger $\begin{array}{c}\text { Candida } \\
\text { glabrata }\end{array}$ \\
\hline 1. & Crude & $65 \pm 0.56$ & $63 \pm 0.78$ & $45 \pm 0.83$ & $58 \pm 0.72$ & $40 \pm 0.54$ \\
2. & $n$-hexane $\left(\mathrm{C}_{6} \mathrm{H}_{14}\right)$ & $50 \pm 0.32$ & $40 \pm 0.86$ & $26 \pm 0.52$ & $54 \pm 0.28$ & $36 \pm 0.91$ \\
3. & Chloroform $\left(\mathrm{CHCl}_{3}\right)$ & $31 \pm 0.67$ & $29 \pm 0.54$ & $30 \pm 0.40$ & $23 \pm 0.35$ & $31 \pm 0.22$ \\
4. & Ethyl acetate (EtoAc) & $60 \pm 0.94$ & $57 \pm 0.51$ & $40 \pm 0.88$ & $48 \pm 0.30$ & $33 \pm 0.82$ \\
5. & $n$-butanol (BuOH) & $37 \pm 0.59$ & $24 \pm 0.29$ & $21 \pm 0.47$ & $35 \pm 0.66$ & $22 \pm 0.65$ \\
6. & Aqueous & $21 \pm 0.29$ & $10 \pm 0.30$ & $21 \pm 0.25$ & $17 \pm 0.56$ & $20 \pm 0.43$ \\
7. & Miconazole (standard) & 100 & 100 & 100 & 100 & 100 \\
\hline
\end{tabular}

\subsection{Bioscreening of Compounds}

Antibacterial and antifungal activities of compounds 1 to 7 were performed, applying previously described disc and agar diffusion methods, respectively, as referenced in the Materials and Methods section, in detail. The zone of inhibition of isolated compounds 1 to 7 has been tabulated in (Tables 3 and 4). Compounds 1, 4, 5, and 6 were active against all the tested range of bacteria, while compounds 2,3 , and 7 were less diverse in their activity against some bacteria. In antifungal activities, all seven compounds showed activity; however, compounds 1, 3, 4, 5, and $\mathbf{6}$ were more active than compounds $\mathbf{2}$ and $\mathbf{7}$.

Table 3. Antibacterial activities showing zone of inhibition $(\mathrm{mm}) \pm$ standard error mean of compounds 1-7 $(28 \mu \mathrm{g} / \mathrm{mL})$ isolated from Onosma chitralicum.

\begin{tabular}{ccccccc}
\hline S.\# & Compounds & E. coli & $\begin{array}{c}\boldsymbol{P} \text {. } \\
\text { aeruginosa }\end{array}$ & S.aureus & S. typhi & B. subtilis \\
\hline $\mathbf{1 .}$ & Compd. 1 & $7 \pm 0.23$ & $2 \pm 0.42$ & $10 \pm 0.45$ & $10 \pm 0.21$ & $2 \pm 0.66$ \\
$\mathbf{2 .}$ & Compd. 2 & $8 \pm 0.57$ & 0 & $5 \pm 0.45$ & 0 & 0 \\
$\mathbf{3 .}$ & Compd. 3 & 0 & $2 \pm 0.20$ & $4 \pm 0.76$ & 0 & $7 \pm 0.25$ \\
$\mathbf{4 .}$ & Compd. 4 & $9 \pm 0.23$ & $1 \pm 0.87$ & $4 \pm 0.61$ & $5 \pm 0.19$ & $5 \pm 0.32$ \\
$\mathbf{5 .}$ & Compd. 5 & $3 \pm 0.54$ & $2 \pm 0.46$ & $3 \pm 0.21$ & $1 \pm 0.23$ & $6 \pm 0.32$ \\
$\mathbf{6 .}$ & Compd. 6 & $6 \pm 0.88$ & $2 \pm 0.65$ & $9 \pm 0.20$ & $10 \pm 0.77$ & $3 \pm 0.51$ \\
$\mathbf{7 .}$ & Compd. 7 & $6 \pm 0.37$ & 0 & $6 \pm 0.36$ & $2 \pm 0.29$ & 0 \\
$\mathbf{8 .}$ & Levofloxacin & $17 \pm 0.17$ & $10 \pm 0.15$ & $23 \pm 0.34$ & $21 \pm 0.20$ & $19 \pm 0.13$ \\
\hline
\end{tabular}

Table 4. Antifungal activities of compounds 1-7 $(28 \mu \mathrm{g} / \mathrm{mL})$ isolated from Onosma chitralicum.

\begin{tabular}{ccccccc}
\hline S. \# & Compounds & A. flavus & F. Solani & $\begin{array}{c}\text { A. } \\
\text { fumigatus }\end{array}$ & A. niger & $\begin{array}{c}\text { C. } \\
\text { glabrata }\end{array}$ \\
\hline 1. & Compd. 1 &,++ &,++ &,++ &,++ &,++ \\
2. & Compd. 2 &,++ &,-- &,-- &,-- &,-- \\
3. & Compd. 3 &,-- &,-- &,-- &,-- &,-- \\
4. & Compd. 4 &,++ &,++ &,-- &,++ &,-- \\
5. & Compd. 5 &,++ &,++ &,-- &,++ &,-- \\
6. & Compd. 6 &,++ &,++ &,-- &,++ &,-- \\
7. & Compd. 7 &,++ &,-- &,-- &,++ &,,,++++ \\
8. & Clotrimazole &,,,++++ &,,,++++ &,,,++++ &,,+++ &,,+++
\end{tabular}




\subsection{Structure-Activity Relationship of the Reported Compounds}

Flavonoids are a class of organic secondary plant phenolic compounds with significant antioxidant and chelating properties. In the human diet, they are most concentrated in fruits, vegetables, wines, teas, and cocoa. Their cardioprotective effects stem from the ability to inhibit lipid peroxidation, chelate redox-active metals, and attenuate other processes involving reactive oxygen species [11]. Despite some inconsistent lines of evidence, several structure-activity relationships are well established in vitro. Multiple hydroxyl groups confer upon the molecule substantial antioxidant, chelating, and pro-oxidant activity. Methoxy groups introduce unfavorable steric effects and increase lipophilicity. A double bond and carbonyl function in the heterocycle or polymerization of the nuclear structure increases activity by affording a more stable flavonoid radical through conjugation and electron delocalization. Further investigation of the metabolism of these phytochemicals is justified to extend structure-activity relationships (SARs) to preventive and therapeutic nutritional strategies [11].

The effectiveness of flavonoids is reflected in the double bond between C-2 and C3 , which is responsible for the planar structure, as well as for conjugation. Both these characteristics are involved in the antioxidant activity of flavonoids [12]. In the isolated compounds, 1, 4, 5, and 7 reflect this property. Another important combination of functional groups and their position is the hydroxyl group at positions 5 and 3 along with the oxo group at position 4 . This combination also contributes to the antioxidant activity of flavonoids [12]. Here, in our reported structures, compounds 2 and $\mathbf{6}$ have $\mathrm{OH}$ at C-3, 4-oxo group, and $\mathrm{C}-5-\mathrm{OH}$ group. A 2,3-double bond in ring-C further increases the antioxidant effects of ring $B$ hydroxyl groups by extending electron delocalization [13]. A double bond conjugates with 4-oxo function, which increases electron delocalization to ring B. This double bond conjugation and 4-oxo functionality are present in active compounds $\mathbf{1}$ and $\mathbf{7}$, with compound 7 , the functional $\mathrm{OH}$ group at $\mathrm{C}-5^{\prime}$. The phenoxy radicals produced here are stabilized by the resonance effect of the aromatic nucleus [14].

The hydroxyl substitution pattern is an indicator of antibacterial activity for flavones, and the additional hydroxyl group at the $4^{\prime}$ position significantly increases the activity, while the methylation of these hydroxyl groups reduces the antibacterial potential at different levels. Moreover, the addition of the 3-hydroxyl group seems to enhance the activity, indicating flavonols may be better antibacterial agents than flavones $[15,16]$. Here, in our reported compounds, 1, 5, 6, 7 have methoxy substitution at position $4^{\prime}$, whereas compound 4 has hydroxyl group at this position.

Based on structure-activity relationships of flavonoids, the double bond between carbon $2^{\prime}$ and $3^{\prime}$ in the B-ring, $\mathrm{OH}$ groups at $\mathrm{C}-7$ in the ring-A collectively played an important role in antimicrobial activities [17]. In our study, the first condition of the double bond between carbon $2^{\prime}$ and $3^{\prime}$ in ring-B is present in all compounds $1-7$, the second condition of $\mathrm{OH}$ group at $\mathrm{C}-7$ in ring-A is exhibited by compounds 1, 4, 7 .

Further, it is reported that the hydroxyl group at positions 3,4 , and 5 in ring-B of flavonoids is responsible for antimicrobial activities against $P$. vulgaris and S. aureus [18]. In our results, compound 4 has $\mathrm{OH}$ group at $\mathrm{C}-4^{\prime}$ and is active against $E$. coli, compound $\mathbf{6}$ at C-3' shows significant inhibition activity against $S$. aureus and S. typhi, and compound 7 at C-5' is active against $S$. aureus. Moreover, these isolated compounds 4, 6, and 7, show the highest binding affinity to the bacterial and fungal proteins in docking results. Detailed binding interaction of compound 7 against beta-hydroxyacyl-ACP dehydratase HadAB is shown in Figure 2. Compound 6, showing strong binding affinity against the bacterial S. aureus tyrosyl-tRNA synthetase target, is shown in Figure 3. Whereas, interaction of compound 7 with S. cerevisiae lanosterol $14 \alpha$-demethylase (CYP51) is provided in Figure 4. These results are summarized in Tables 5-11. 


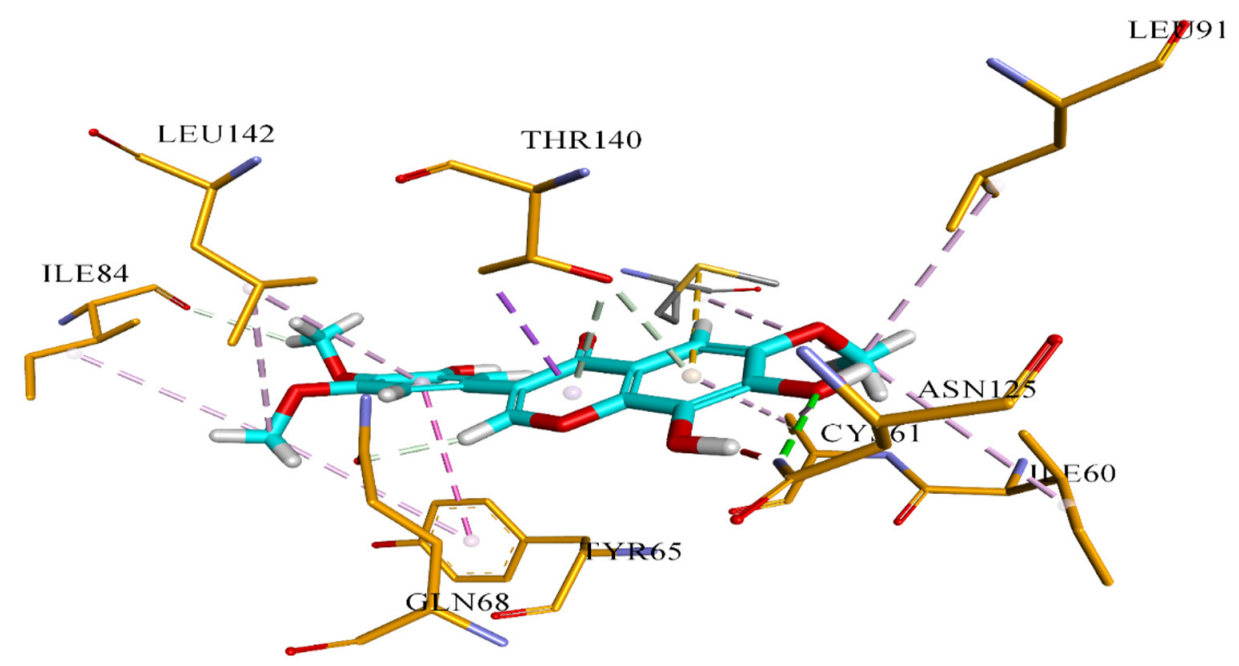

Figure 2. Putative binding interaction of compound 7 against bacterial beta-hydroxyacyl-ACP dehydratase HadAB.

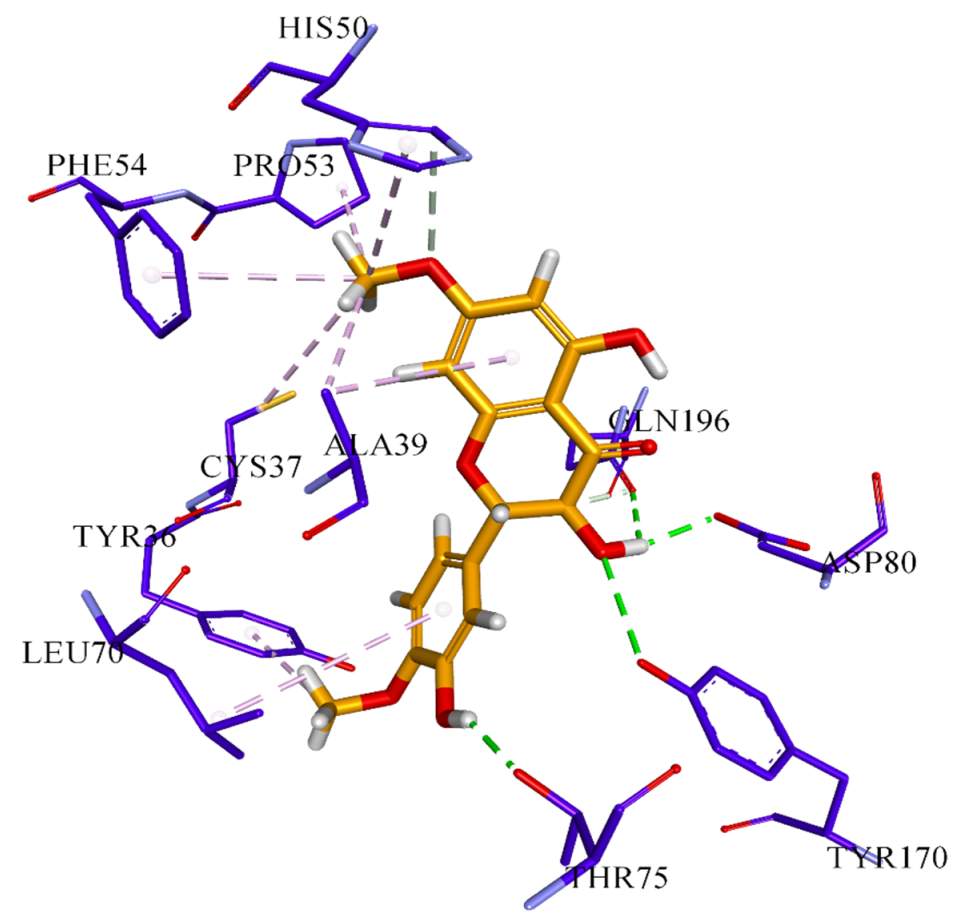

Figure 3. Putative binding interaction of compound 6 against bacterial S. aureus tyrosyl-tRNA synthetase.

Interestingly, a report published by Stapleton and colleagues explains that substitution with C-8 and C-10 chains also enhanced the anti-staphylococcal activity of flavonoids [19], as compounds 1 and 7 have this substitution with $\mathrm{OCH} 3$ and $\mathrm{OH}$ groups, respectively. It was also reported by Osawa and colleagues that 5-hydroxyflavones and 5-hydroxyisoflavones with additional hydroxyl groups at the 7 and $4^{\prime}$ positions lost the inhibitory activity [20], whereas, in compound 6 (active) the positions 7 and $4^{\prime}$ are substituted with OCH3 and can be the reason for its activity. Besides the unsaturation and hydroxylation in-ring system, another most important function in the structure of flavonoids that relates its antifungal activity is methylation. The main classes of antimicrobial and antiviral flavonoids found in medicinal plants are methylated flavones and flavonols. It is reported that methylated flavonoids have antimicrobial activities against bacteria $S$. aureus and fungus C. albicans [18]. In our case, all seven purified compounds are methylated. However, the antimicrobial activity of each compound is different. 


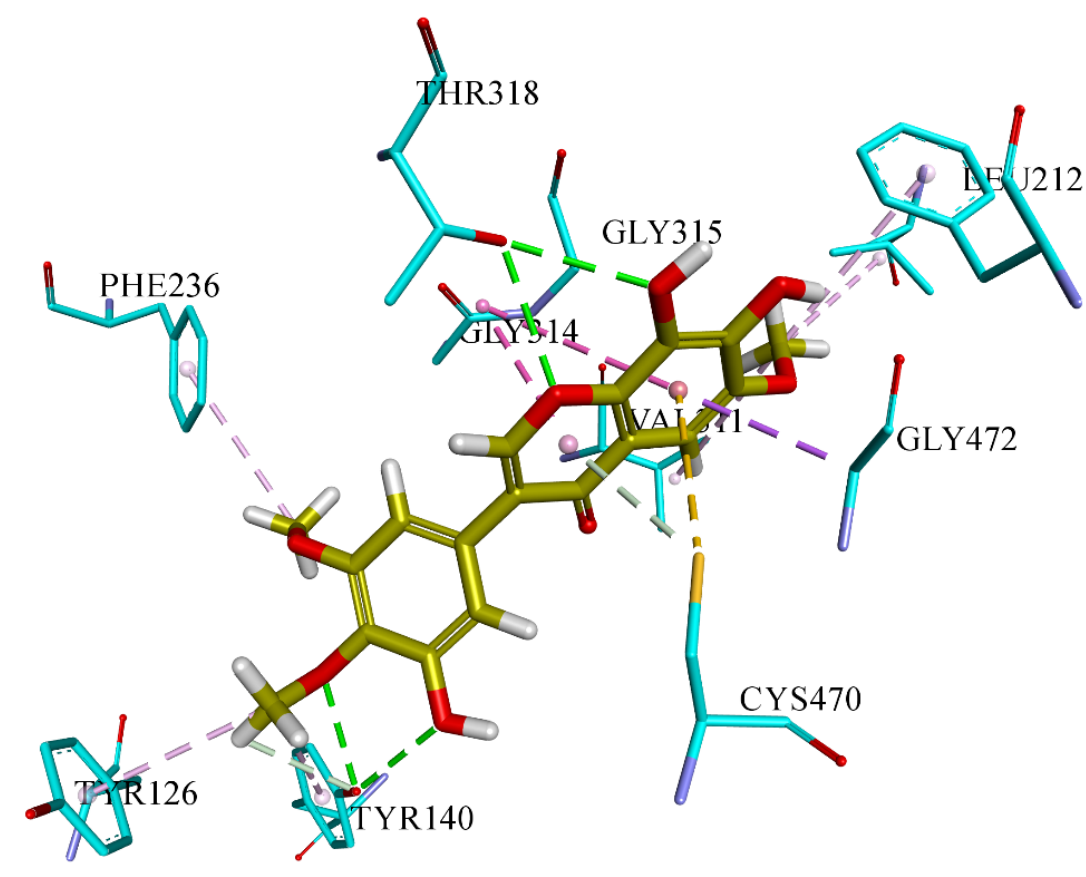

PHE475

Figure 4. Putative binding interaction of compound 7 against lanosterol $14 \alpha$-demethylase enzyme.

As demonstrated in Tables 3 and 4, compound $\mathbf{1}$ has promising antimicrobial activity against the selected bacterial and fungal strains due to the best position of functional groups, i.e., hydroxylation at position 7 of ring $\mathrm{A}$, presence of double bond between carbon $2^{\prime}$ and $3^{\prime}$ in-ring $\mathrm{B}$, and delocalization of ring- $\mathrm{C}$ with ring $\mathrm{B}$. The next active compound is 6 with active $\mathrm{OH}$ at $\mathrm{C}-3^{\prime}$, with a double bond between $\mathrm{C}-2$ and $\mathrm{C}-3$, showing good inhibition activity, and it has $\mathrm{OH}$ at $\mathrm{C}-3$ with 4-oxo group and $\mathrm{C}-5-\mathrm{OH}$ group in conjugation, stabilizing, and conjugating the ring system. The compounds 2,3, and 6 have carbon 2 and 3 saturated, which makes them non-planar and more reactive in comparison.

\subsection{Molecular Docking Studies}

Nowadays molecular docking calculations are broadly used for investigating the binding affinities of ligands with target structure. Molecular docking studies were performed for all seven isolated and characterized compounds, to investigate the putative binding orientation within the active site of three bacterial proteins and one fungal target protein. Bacterial Staphylococcus aureus tyrosyl-tRNA synthetase and topoisomerase-II DNA gyrase, as well as Mycobacterium tuberculosis beta-hydroxyacyl-ACP dehydratase HadAB, whereas the Fungal Saccharomyces cerevisiae lanosterol 14 $\alpha$-demethylase (CYP51), are attractive therapeutic targets for the design and development of antibacterial and antifungal drugs. The crystal structure coordinates of the bacterial FabZ complexed with inhibitor Fisetin were retrieved from the Protein Data Bank PDB (PDB code: 4RLT) [21], Staphylococcus aureus tyrosyl-tRNA synthetase in with complex with SB-239629 (PDB code: 1JIJ) [22], topoisomerase-II DNA gyrase in complex with ciprofloxacin and DNA (PDB id: 2XCT) [23], and Saccharomyces cerevisiae lanosterol 14 $\alpha$-demethylase (CYP51) in complex with fluconazole at the active site (PDB code: $4 \mathrm{WMZ}$ ) [24].

The binding affinity of all seven compounds against the aforementioned four target proteins was evaluated based on Chemguass4 score implemented in FRD docking software. Fast rigid exhaustive docking (FRED) uses a multi-conformer docking procedure, which separately creates a set of low-energy conformers, and then does rigid docking for each conformer. Three parameters were used for docking analysis: the binding affinity expressed in $\mathrm{kcal} / \mathrm{mol}$, the interactions between the ligand atoms, amino acid residues of the target protein, and the distance of these interactions. The binding affinity of these compounds shows the highest binding value with $M$. tuberculosis beta-hydroxyacyl-ACP dehydratase 
HadAB compared to the lowest from the $S$. aureus topoisomerase II DNA gyrase, as shown in Tables 5, 7, 9 and 11. Compound 7 was found to form the most stable complex with betahydroxyacyl-ACP dehydratase HadAB and also S. cerevisiae lanosterol $14 \alpha$-demethylase (CYP51), owing to the Chemguass4 score of $-15.2557,-11.57$, respectively. Whereas, compound 6 indicated strong binding interaction with S. aureus tyrosyl-tRNA synthetase at a Chemguass 4 score of -13.12 . Moreover, the detailed binding interaction of compound 6, showing strong binding affinity against the bacterial S. aureus tyrosyl-tRNA synthetase target, is shown in Figure 3 and summarized in Table 8.

The bacterial fatty synthase-II is lacking in mammals (mammal have fatty acid synthase-I) and, therefore, it has recently attracted much attention as a potential antibacterial drug target. FabZ is a ubiquitous component of the bacterial fatty acid synthesis pathway. This enzyme catalyzes the dehydration of beta-hydroxyacyl-ACP to trans-2acyl-AC and, therefore, called Had (Hydroxyacyl dehydratase) [25]. FabZ is a ubiquitous component of the bacterial fatty acid synthesis pathway, ubiquitously present in Grampositive and Gram-negative bacteria [25]. This enzyme has been extensively studied as an effective drug target in various pathogenic bacteria, including S. aeruginosa [26], Helicobacter pylori [27], etc. Flavonoids, such as fisetin, have been shown to inhibit the FabZ in a number of studies, by perturbing the binding of the substrate in the active site and obstruct the placement of fatty acids in the channel in the HadA at the dimer interface [25]. Fisetin is a plant-derived polyphenol flavonoid, having antibacterial, antioxidant, and anticancer activities [28].

Table 5. FRED score of all compound (compounds 1-7) against docking in beta-hydroxyacyl-ACP dehydratase HadAB (Protein Data Bank (PDB) ID: 4rlt) as a potential antibacterial target.

\begin{tabular}{cc}
\hline Compound Code & FRED Chemguass4 Score \\
\hline Compd_1 & -12.3517 \\
Compd_2 & -13.9049 \\
Compd_3 & -13.2884 \\
Compd_4 & -14.5556 \\
Compd_5 & -12.9227 \\
Compd_6 & -15.1099 \\
Compd_7 & -15.2557 \\
4RLT_cc & -14.8466 \\
\hline
\end{tabular}

Table 6. Detailed analysis of compound 7 against docking in beta-hydroxyacyl-ACP dehydratase HadAB (PDB ID: 4rlt) as a potential antibacterial target.

\begin{tabular}{ccc}
\hline Type of Bond & Distance & Interacting Amino Acid of Target \\
\hline Hydrogen Bond & 3.04121 & A:ASN125:ND2 \\
Hydrogen Bond & 2.21139 & A:GLN68:OE1 \\
Hydrogen Bond & 2.76714 & A:ILE84:O \\
Hydrogen Bond & 3.41761 & A:THR140:OG1 \\
Hydrogen Bond & 3.87218 & A:THR140:OG1 \\
Pi-Sigma & 3.87034 & A:THR140:CG2 \\
Pi-Sulfur & 5.56442 & B:MET60:SD \\
Pi-Pi T-shaped & 4.88136 & A:TYR65 \\
Hydrophobic & 4.79327 & A:ILE84 \\
Hydrophobic & 4.89475 & A:LEU142 \\
Hydrophobic & 5.17456 & A:ILE60 \\
Hydrophobic & 3.9138 & A:CYS61 \\
Hydrophobic & 4.94236 & A:LEU91 \\
Hydrophobic & 5.33226 & B:MET60 \\
Hydrophobic & 5.37435 & A:LEU142 \\
Hydrophobic & 5.37548 & A:CYS61 \\
Hydrophobic & 5.48466 & A:TYR65 \\
\hline
\end{tabular}


Table 7. FRED score of all compound (compounds 1-7) against docking in S. aureus tyrosyl-tRNA synthetase (PDB ID: 1jij) as a potential antibacterial target.

\begin{tabular}{cc}
\hline Compound Code & FRED Chemguass4 Score \\
\hline Compd_1 & -11.39 \\
Compd_2 & -10.67 \\
Compd_3 & -11.30 \\
Compd_4 & -11.75 \\
Compd_5 & -9.79 \\
Compd_6 & -13.12 \\
Compd_7 & -12.93 \\
Co-crystalized ligand & -14.64 \\
\hline
\end{tabular}

Lanosterol $14 \alpha$-demethylase enzyme catalyzes an essential step in the synthesis of ergosterol, which is an essential component of the fungal cell membrane. CYP51 is the target of azoles, the most popular class of antifungal drugs. There has been a considerable amount of research interest into this enzyme and the azoles because of the dramatically increasing number of drug resistance among certain fungal species. Molecular docking of all seven compounds against Lanosterol $14 \alpha$-demethylase enzyme revealed that compound 7 was forming the most stable complex with the lanosterol $14 \alpha$-demethylase enzyme, owing to the Chemguass 4 score of -11.57 . Detailed binging interactions of compound 7 are shown in Figure 4 and summarized in Table 10.

Table 8. Detailed analysis of compound 6 against docking in S. aureus tyrosyl-tRNA synthetase (PDB ID: 1jij) as a potential antibacterial target.

\begin{tabular}{ccc}
\hline Type of Bond & Distance $(\AA)$ & Interacting Amino Acid of Target \\
\hline Hydrogen Bond & 3.02926 & A:TYR170:OH \\
Hydrogen Bond & 2.11983 & A:THR75:OG1 \\
Hydrogen Bond & 2.07234 & A:ASP80:OD2 \\
Hydrogen Bond & 2.66497 & A:GLN196:OE1 \\
Hydrogen Bond & 3.53206 & A:HIS50:CD2 \\
Hydrogen Bond & 2.08403 & A:GLN196:OE1 \\
Hydrophobic & 4.41402 & A:ALA39 \\
Hydrophobic & 5.21473 & A:CYS37 \\
Hydrophobic & 4.58554 & A:PRO53 \\
Hydrophobic & 4.46255 & A:TYR36 \\
Hydrophobic & 4.44049 & A:HIS50 \\
Hydrophobic & 4.45421 & A:PHE54 \\
Hydrophobic & 5.31681 & A:LEU70 \\
Hydrophobic & 4.82878 & A:ALA39 \\
\hline
\end{tabular}

Table 9. FRED score of all compounds (compound 1-7) against docking in lanosterol $14 \alpha$-demethylase enzyme (PDB ID: 4wmz) as a potential antifungal target.

\begin{tabular}{cc}
\hline Compound Code & FRED Chemguass4 Score \\
\hline Compd_1 & -10.03 \\
Compd_2 & -10.61 \\
Compd_3 & -9.88 \\
Compd_4 & -11.07 \\
Compd_5 & -10.06 \\
Compd_6 & -11.44 \\
Compd_7 & -11.57 \\
Co-crystalized ligand & -11.25 \\
\hline
\end{tabular}

The docking process was validated by redocking the co-crystallized ligand and found bound to the binding pocket with similar ligand-protein interactions. Binding pockets of Mycobacterium tuberculosis beta-hydroxyacyl-ACP dehydratase HadAB (PDB 
code: 4RLT) with docked compound 7 (5',7,8-trihydroxy-6,3', $4^{\prime}$-trimethoxyflavanone), and S. aureus tyrosyl-tRNA synthetase (PDB ID: 1JIJ) with docked compound 6 (5,3',3trihydroxy-7, $4^{\prime}$-dimethoxyflavanone) are visualized by molecular visualization program UCSF chimera [29], as shown in Figure 5.

(a)

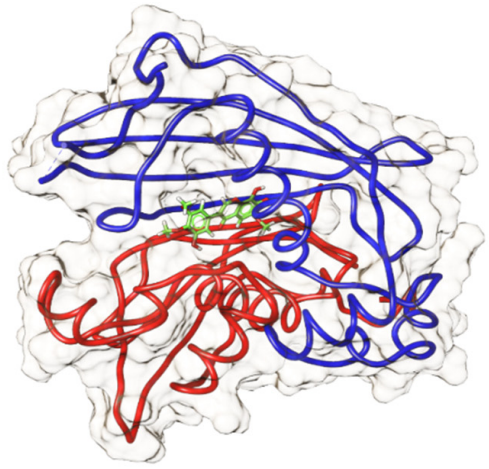

(c)

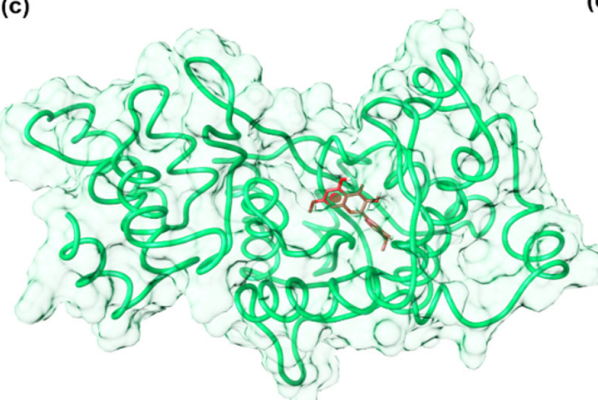

(b)

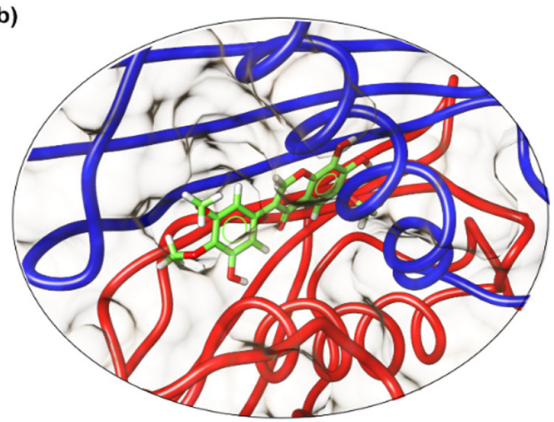

(d)

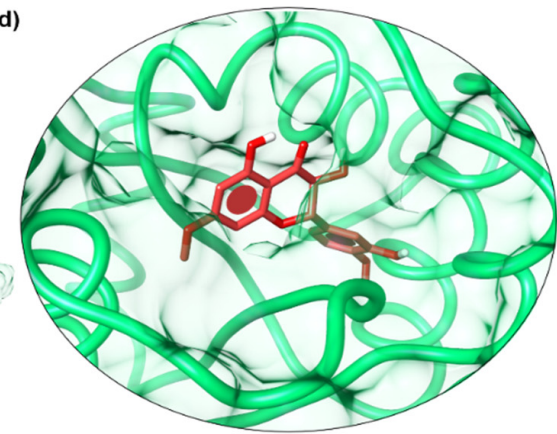

Figure 5. Binding pocket visualization of important bacterial potential enzyme targets docked with isolated compounds from Onosma chitralicum. $(\mathbf{a}, \mathbf{b})$ Compound $\mathbf{7}$ docked with $M$. tuberculosis betahydroxyacyl-ACP dehydratase $\mathrm{HadAB}$, and bound in the same location, i.e., the channel at the dimer interface where the co-crystallized ligand fisetin was found in the pocket in the reported PDB. Compound 7 is shown in green stick representation and the dimeric protein with blue and green protomers. (c,d) Docked compound $\mathbf{6}$ (shown in red sticks) binds to the active site pocket of $S$. aureus tyrosyl-tRNA synthetase (in green ribbon).

Table 10. Detailed analysis of compound 7 against docking in lanosterol $14 \alpha$-demethylase enzyme (PDB ID: 4wmz) as a potential antifungal target.

\begin{tabular}{ccc}
\hline Type of Bond & Distance (A) & Interacting Amino Acid of Target \\
\hline Hydrogen Bond & 3.11333 & A:TYR140:OH \\
Hydrogen Bond & 2.85993 & A:TYR140:OH \\
Hydrogen Bond & 2.96137 & A:THR318:OG1 \\
Hydrogen Bond & 2.96662 & A:THR318:OG1 \\
Hydrogen Bond & 3.03261 & A:TYR140:OH \\
Pi-Sigma & 3.98031 & A:CYS470:SG \\
Pi-Sulfur & 3.72732 & A:GLY472:CA \\
Amide-Pi Stacked & 4.25042 & A:CYS470:SG \\
Amide-Pi Stacked & 4.6864 & A:GLY314:C,O;GLY315:N \\
Hydrophobic & 3.99431 & A:GLY314:C,O;GLY315:N \\
Hydrophobic & 4.82112 & A:LEU212 \\
Hydrophobic & 5.10465 & A:VAL311 \\
Hydrophobic & 4.45331 & A:TYR126 \\
Hydrophobic & 5.29002 & A:TYR140 \\
Hydrophobic & 4.8273 & A:PHE236 \\
\hline
\end{tabular}


Table 11. FRED score of all compound (compounds 1-7) against docking in topoisomerase II DNA gyrase (PDB ID: 2xct) as a potential antibacterial target.

\begin{tabular}{cc}
\hline Compound Code & FRED Chemguass4 Score \\
\hline Compd_1 & -2.20 \\
Compd_2 & -2.43 \\
Compd_3 & -2.47 \\
Compd_4 & -3.35 \\
Compd_5 & -1.70 \\
Compd_6 & -2.29 \\
Compd_7 & -2.17 \\
Co-crystalized ligand & -3.25 \\
\hline
\end{tabular}

The Saccharomyces cerevisiae lanosterol $14 \alpha$-demethylase (CYP51) (PDB ID: 4WMZ) docked with compound 7 and $S$. aureus topoisomerase-II DNA gyrase (PDB ID: 2XCT) with compound 4 (7, $4^{\prime}$-dihydroxy-3'-methoxyisoflavone) with very interesting DNA binding aptitude similar to bound co-crystallized ligand ciprofloxacin, visualized by molecular visualization program PyMOL [30], as shown in Figure 6.

(a)

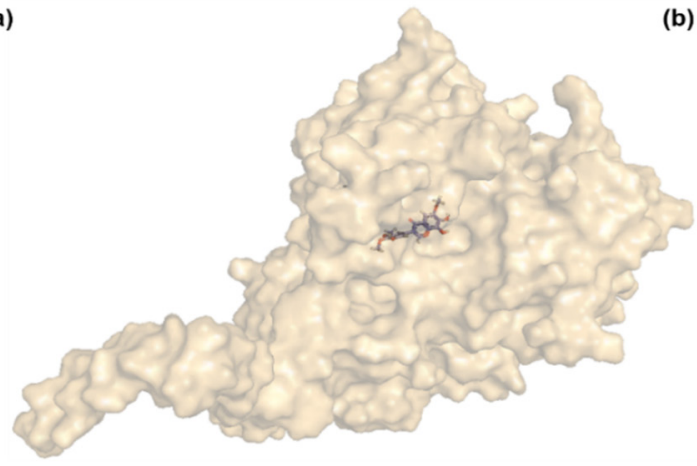

(b)

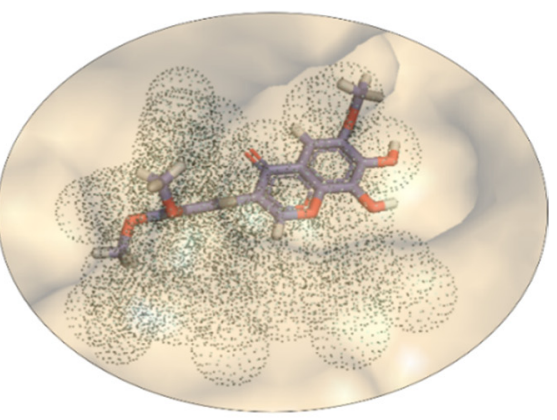

(c)

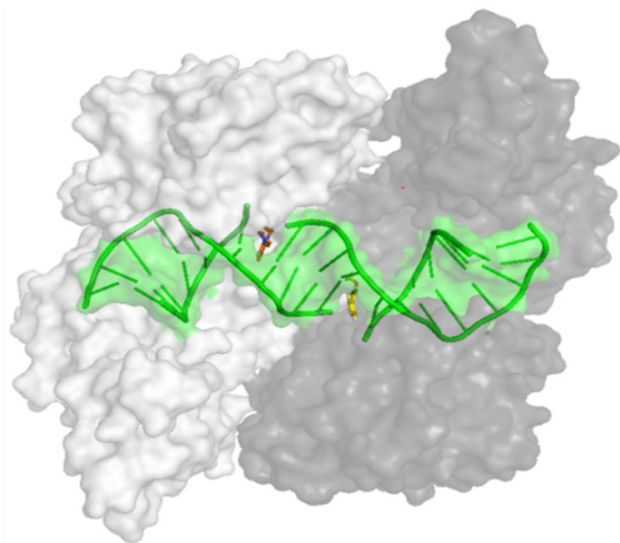

(d)

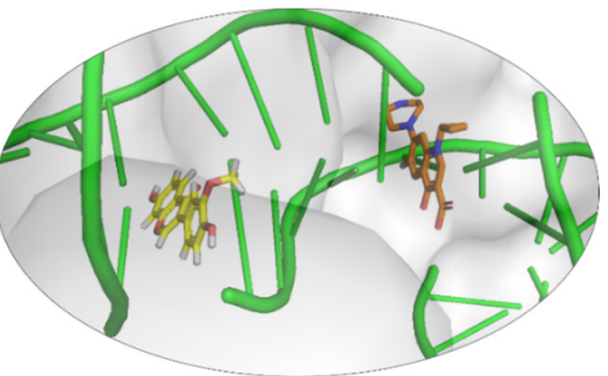

Figure 6. Binding pocket visualization of $(\mathbf{a}, \mathbf{b})$ yeast $S$. cerevisiae lanosterol $14 \alpha$-demethylase enzyme (a cytochrome P450 enzyme) docked with compound 7 isolated from Onosma chitralicum. The enzyme is reported in a co-crystallized form with fluconazole under PDB code $4 \mathrm{WMZ}$. Compound 7 (shown in stick form) is visible in the dotted binding pocket, showing that this compound can act as a potential pro-drug and be modified for fitting in the active site groove. $(\mathbf{c}, \mathbf{d})$ Docked compound 4 is found in the mirror image form of ciprofloxacin, co-crystallized with S. aureus topoisomerase-II DNA gyrase (PDB ID: 2XCT), involved in hydrogen bonding to the bound DNA molecule. Ciprofloxacin and compound 4 are shown in sticks, bound DNA in green ribbon, and dimeric enzyme in white and black protomers with surface representation. 


\section{Materials and Methods}

\subsection{Collection of Plant Material}

Chitral city is the source of the Onosma chitralicum plant. This plant was recognized by Dr. Nisar Ahmad, Department of Botany, KUST, Kohat, KP, Pakistan, with (PSK 67) as a voucher specimen deposited there.

\subsection{Extraction, Fractionation, and Bioassays}

The shade and air-dried plant Onosma chitralicum $(2 \mathrm{~kg})$ were taken and ground to get powder, soaked in methanol $(4 \mathrm{~L})$ for 14 days, and were extracted three times during the 14 days at room temperature in the same solvent, and then filtered. The filtrates were evaporated under reduced pressure by vacuum rotary evaporator at $35^{\circ} \mathrm{C}$. The extract was dried and weighed. The crude extract weighed to $80 \mathrm{~g}$, was further suspended in water, and partitioned successively with $\mathrm{n}$-hexane, chloroform, ethyl acetate, and $n$-butanol to obtain their soluble fractions. The weight of each solvent soluble fraction was $n$-hexane $(15 \mathrm{~g})$, chloroform (25 g), ethyl acetate soluble (18 g), $n$-butanol (12 g), and aqueous fraction (10 g).

Antibacterial and antifungal activities of the crude extract, other solvent soluble fractions, and the compounds 1-7 isolated from Onosma chitralicum were investigated. Bacterial strains, such as Escherichia coli, Pseudomonas aeruginosa, Staphylococcus aureus, Salmonella typhi, and Bacillus subtilis were used in antibacterial essay while fungal strains Aspergillus flavus, Fusarium solani, Aspergillus fumigates, Aspergillus niger, and Candida glabrata were used in antifungal assay. The bacterial and fungal strains used in this study were clinical isolates that were isolated and identified previously at Department of Microbiology of this university. Disc diffusion method was used for antifungal activity, while for antibacterial activities, the agar well diffusion method was used. In the disc diffusion technique, the bacterial culture was streaked on the surface of the solidified agar media in the sterile petri plate. Next, on the sterile disc, $10 \mu \mathrm{L}$ of the extract or fraction and isolated compounds from their stock solutions were allowed to absorb in independent experiments, and zones of inhibition were measured after $24 \mathrm{~h}$ of incubation [31].

In the agar-well diffusion method for bacterial strains, wells of $6 \mathrm{~mm}$ were dug in the sterile agar media by using a sterile plastic borer. Next, each well was given a specific number, and bacterial culture was inoculated on the surface of the solidified media. Stock solutions of crude extracts and fractions in one experiment and the isolated compounds in another experiment were added into respective wells. The zones of inhibition were measured after $24 \mathrm{~h}$ of incubation at $37^{\circ} \mathrm{C}$ in an incubator [32]. Doxycycline and Miconazole were used in the crude assays, whereas, levofloxacin and clotrimazole were used in the isolated compounds screening as standard positive controls, while DMSO was used as a negative control. The zones of inhibition of crude extract, fractions, and the isolated compounds were compared with the zones of inhibition of standard drugs.

\subsection{Isolation of Chemical Constituents}

The most potent activity was observed in ethyl acetate fraction and was further subjected to separation protocol using column chromatography. The elution through column chromatography was carried out based on the gradient of polarity $\left(n-\mathrm{C}_{6} \mathrm{H}_{14} \rightarrow n-\mathrm{C}_{6} \mathrm{H}_{14^{-}}\right.$ EtOAc $\rightarrow$ pure-EtOAc). As a result, four fractions $A$, fractions $B$, fractions $\mathrm{C}$ and fractions D were obtained by eluting $n-\mathrm{C}_{6} \mathrm{H}_{14}$-EtOAc of different fractions through column chromatography. Fraction A was obtained by using $n-\mathrm{C}_{6} \mathrm{H}_{14}$-EtOAc (8:2), consisted of two pure compounds, compound $\mathbf{1}\left(4^{\prime}, 8\right.$-dimethoxy-7-hydroxyisoflavone) [33] and compound 3 (2,3-dihydro-3-hydroxy-7-methoxyflavone) [34] with a ratio of (8.50:1.50 \& 7.50:2.50), respectively. Fraction B was also obtained as discussed above with $n-\mathrm{C}_{6} \mathrm{H}_{14}$-EtOAc (6.0:4.0), consisted of compound 2 (2,3-dihydro-3,5-dihydroxy-7-methoxyflavone) [35] and compound 4 (7,4'-dihydroxy-3'-methoxyisoflavone) [36], with the ratio of (6.50:3.50 and 6.50:4.0), respectively. Fraction $\mathrm{C}$ was eluted by using $n-\mathrm{C}_{6} \mathrm{H}_{14}$-EtOAc at the ratio of (9:1) was further subjected to column chromatography. Fraction $\mathrm{C}$ afforded only one pure compound, compound 5 (7, $4^{\prime}$-dimethoxy-isoflavone) [37]. Fraction D was 
eluted with $n-\mathrm{C}_{6} \mathrm{H}_{14}$-EtOAc by using the ratio of (5:5) and 2 compounds, compound 6 (5,3',3-trihydroxy-7, $4^{\prime}$-dimethoxyflavanone) [38] and compound 7 (5',7,8-trihydroxy-6, $3^{\prime}, 4^{\prime}$ trimethoxyflavanone) [39] with the ratio of (2.50:7.50 \& 4.50:5.50) were eluted, respectively.

For isolation of compounds, Eyela (EF-10 model) flash chromatography a type of flash column chromatography technique was used by using silica gel (E. Merck Si 60,230-400 mesh).

\subsection{Characterizations Techniques}

The spectra of UV were reported on spectrophotometric instrument Hitachi UV-3200. IR spectral data were measured using a JASCO 302-A spectrophotometer. EI-MS ( $\mathrm{m} / \mathrm{z})$ were recorded on JEOL JMS-HX-110 mass spectrometer. At $400 \mathrm{MHz}$, the spectra of ${ }^{1} \mathrm{H}-\mathrm{NMR}$ were observed on the instrument named Bruker AM-400 AMX spectrometers with the respective frequency data system. TMS of compounds was used as a reference (mainly internally). The spectra of ${ }^{13} \mathrm{C}-\mathrm{NMR}$ (broadband and DEPT or GASPE) were accomplished on the same instruments at $75 \mathrm{MHz}, 100 \mathrm{MHz}$, and $125 \mathrm{MHz}$, respectively. The values of the chemical shift were expressed as ppm $(\delta)$ and the coupling constants $(J)$ values were expressed in $\mathrm{Hz}$.

\subsection{Physical and Spectral Data of Isolated Compounds $\mathbf{1}$ to $\mathbf{7}$}

4',8-dimethoxy-7-hydroxyisoflavone (1): colorless solid. UV $\lambda_{\max }\left(\mathrm{CH}_{3} \mathrm{Cl}\right) 254,350 \mathrm{~nm}$. $\operatorname{IR}(\mathrm{KBr}) \mathrm{cm}^{-1}: 1600,1685,3450,1315,{ }^{1} \mathrm{H}-\mathrm{NMR}\left(\mathrm{CDCl}_{3}, 400 \mathrm{MHz}\right) \delta: 8.33(2 \mathrm{H} \mathrm{s}, J=0 \mathrm{~Hz})$, $7.62(5 \mathrm{H} \mathrm{d}, J=8.3), 6.89(6 \mathrm{H} \mathrm{d}, J=9.4), 7.47\left(2 \mathrm{H}^{\prime} \mathrm{d}, J=8.81\right), 6.94\left(3 \mathrm{H}^{\prime} \mathrm{d}, J=8.81\right), 6.94\left(5 \mathrm{H}^{\prime}\right.$ $\mathrm{d}, J=8.81), 7.47\left(6 \mathrm{H}^{\prime} \mathrm{d}, J=8.81\right), 3.81\left(8 \mathrm{OCH}_{3} \mathrm{~s},\right), 3.79\left(4-\mathrm{OCH}_{3^{\prime}} \mathrm{s},\right) ;{ }^{13} \mathrm{C}-\mathrm{NMR}\left(\mathrm{CDCl}_{3}\right) \delta$ : 154.2 (C-2), 123.2 (C-3), 181.1(C-4), 123.9 (C-5), 122.5 (C-6), 163.1 (C-7), 145.5 (C-8), 159.6 (C-9), $106.1(\mathrm{C}-10), 123.6\left(\mathrm{C}-1^{\prime}\right), 121\left(\mathrm{C}-2^{\prime}\right), 122\left(\mathrm{C}-3^{\prime}\right), 146.5\left(\mathrm{C}-4^{\prime}\right), 122\left(\mathrm{C}-5^{\prime}\right), 121\left(\mathrm{C}-6^{\prime}\right), 58.4$ $\left(8-\mathrm{OCH}_{3}\right), 61.3\left(4-\mathrm{OCH}_{3^{\prime}}\right)$; EI-MS $m / z$ 298. The above physical and spectral data are in complete agreement with the data reported in literature for compound 1 [33].

2,3-dihydro-3,5-dihydroxy-7-methoxyflavone (2): colorless solid. UV $\lambda_{\max }\left(\mathrm{CH}_{3} \mathrm{Cl}\right)$ 250,323 nm. IR(KBr) cm ${ }^{-1}: 1605,1710,3250,1310 ;{ }^{1} \mathrm{H}-\mathrm{NMR}\left(\mathrm{CDCl}_{3}, 400 \mathrm{MHz}\right) \delta: 5.14(2 \mathrm{H} \mathrm{d}$, $J=11.0 \mathrm{~Hz}), 4.54(3 \mathrm{H} \mathrm{d}, J=11.0 \mathrm{~Hz}), 11.04(5 \mathrm{H} \mathrm{s}), 6.05(6 \mathrm{H} \mathrm{d}, J=2.3), 6.18(8 \mathrm{H} \mathrm{d}, J=2.3 \mathrm{~Hz})$, $7.40\left(2 \mathrm{H}^{\prime} \mathrm{m}\right) .5,7.42\left(3 \mathrm{H}^{\prime} \mathrm{m}\right), 7.43\left(4 \mathrm{H}^{\prime} \mathrm{m}\right) 7.47\left(5 \mathrm{H}^{\prime} \mathrm{m}\right), 7.51\left(7 \mathrm{OCH}_{3} \mathrm{~s}\right) ;{ }^{13} \mathrm{C}-\mathrm{NMR}\left(\mathrm{CDCl}_{3}\right)$ 8: 77.2 (C-2), 149.7 (C-3), 181.9(C-4), 158.3 (C-5), 121.5 (C-6), 146.3 (C-7), 122.5 (C-8), 156.3 (C-9), 106.9 (C-10), 122.8 (C-1'), $121.9\left(\mathrm{C}-2^{\prime}\right), 123.2\left(\mathrm{C}-3^{\prime}\right), 123.7\left(\mathrm{C}-4^{\prime}\right), 122.2\left(\mathrm{C}-5^{\prime}\right), 121$. $\left(\mathrm{C}-6^{\prime}\right), 58.3\left(8 \mathrm{OCH}_{3}\right)$; (calcd for $\left.\mathrm{C}_{16} \mathrm{H}_{12} \mathrm{O}_{5} 284\right)$ EI-MS $m / z$ 284. The above physical and spectral data coincided with the data reported in literature for compound 2 [34].

2,3-dihydro-3-hydroxy-7-methoxyflavone (3): colorless solid. $\mathrm{UV} \lambda_{\max }\left(\mathrm{CH}_{3} \mathrm{Cl}\right) 254,350 \mathrm{~nm}$. $\operatorname{IR}(\mathrm{KBr}) \mathrm{cm}^{-1}: 1600,1685,3450,1315 ;{ }^{1} \mathrm{H}-\mathrm{NMR}\left(\mathrm{CDCl}_{3}, 400 \mathrm{MHz}\right) \delta: 8.33(2 \mathrm{H} \mathrm{s}, J=0 \mathrm{~Hz}), 7.62$ $(5 \mathrm{H} \mathrm{d}, J=8.3), 6.89(6 \mathrm{H} \mathrm{d}, J=9.4), 7.47\left(2 \mathrm{H}^{\prime} \mathrm{d}, J=8.81\right), 6.94\left(3 \mathrm{H}^{\prime} \mathrm{d}, J=8.81\right), 6.94\left(5 \mathrm{H}^{\prime}\right.$ $\mathrm{d}, J=8.81), 7.47\left(6 \mathrm{H}^{\prime} \mathrm{d}, J=8.81\right), 3.81\left(8 \mathrm{OCH}_{3} \mathrm{~s}\right), 3.79\left(4 \mathrm{OCH}_{3}{ }^{\prime} \mathrm{s},\right) ;{ }^{13} \mathrm{C}-\mathrm{NMR}\left(\mathrm{CDCl}_{3}\right) \delta$ : 154.2 (C-2), 123.2 (C-3), 181.1(C-4), 123.9 (C-5), 122.5 (C-6), 163.1 (C-7), 145.5 (C-8), 159.6 (C-9), 106.1 (C-10), $123.6\left(\mathrm{C}-1^{\prime}\right), 121\left(\mathrm{C}-2^{\prime}\right), 122\left(\mathrm{C}-3^{\prime}\right), 146.5\left(\mathrm{C}-4^{\prime}\right), 122\left(\mathrm{C}-5^{\prime}\right), 121\left(\mathrm{C}-6^{\prime}\right)$, $58.4\left(8 \mathrm{OCH}_{3}\right), 61.3\left(4 \mathrm{OCH}_{3^{\prime}}\right)$; EI-MS $\mathrm{m} / z$ 268. The above physical and spectral data are in complete agreement with the data reported in literature for compound 3 [35].

7,4'-dihydroxy-3'-methoxyisoflavone (4): colorless solid. $\mathrm{UV} \lambda_{\max }\left(\mathrm{CH}_{3} \mathrm{Cl}\right) 255,336 \mathrm{~nm}$. $\operatorname{IR}(\mathrm{KBr}) \mathrm{cm}^{-1}: 1610,1680,3450,1325 ;{ }^{1} \mathrm{H}-\mathrm{NMR}\left(\mathrm{CDCl}_{3}, 400 \mathrm{MHz}\right) \delta: 5.14(2 \mathrm{H} \mathrm{d}, J=11.2 \mathrm{~Hz})$, $7.80(5 \mathrm{H} \mathrm{d}, J=8.9), 6.90(6 \mathrm{H} \mathrm{d}, J=8.9), 6.49(8 \mathrm{H} \mathrm{d}, J=2.7 \mathrm{~Hz}), 7.19\left(2 \mathrm{H}^{\prime} \mathrm{d}, J=1.5\right), 7.42$ $\left(3 \mathrm{H}^{\prime} \mathrm{m}\right), 6.76\left(5 \mathrm{H}^{\prime} \mathrm{d}, J=8.0\right) 6.79\left(6 \mathrm{H}^{\prime} \mathrm{d}, J=8.0\right), 3.76\left(3-\mathrm{OCH}_{3}\right) ;{ }^{13} \mathrm{C}-\mathrm{NMR}\left(\mathrm{CDCl}_{3}\right) \delta: 151.4$ (C-2), 153.5 (C-3), 173.5(C-4), 126.5 (C-5), 121.8 (C-6), 165.9 (C-7), 102 (C-8), 156.9 (C-9), 115.8 (C-10), $123.8\left(\mathrm{C}-1^{\prime}\right), 114.3\left(\mathrm{C}-2^{\prime}\right), 148.1\left(\mathrm{C}-3^{\prime}\right), 145.4\left(\mathrm{C}-4^{\prime}\right), 114.1\left(\mathrm{C}-5^{\prime}\right), 118.5\left(\mathrm{C}-6^{\prime}\right)$; EI-MS $m / z$ 284. The above physical and spectral data are similar with the data reported in literature for compound 4 [36].

7,4'-dimethoxy-isoflavone (5): colorless solid. UV $\lambda_{\max }\left(\mathrm{CH}_{3} \mathrm{Cl}\right) 250,323 \mathrm{~nm} . \mathrm{IR}(\mathrm{KBr})$ $\mathrm{cm}^{-1}: 1605,1670,3350,1340 ;{ }^{1} \mathrm{H}-\mathrm{NMR}\left(\mathrm{CDCl}_{3}, 400 \mathrm{MHz}\right) \delta: 7.96(2 \mathrm{H}, \mathrm{s}), 8.31(5 \mathrm{H} \mathrm{d}$, $J=9.3 \mathrm{~Hz}), 6.97(6 \mathrm{H} \mathrm{dd}, J=9.3,2.5), 6.87(8 \mathrm{H} \mathrm{d}, J=2.5), 7.40\left(2 \mathrm{H}^{\prime} \mathrm{d}, J=8.1\right), 7.42\left(5 \mathrm{H}^{\prime} \mathrm{d}\right.$, $J=8.4), 7.40\left(6 \mathrm{H}^{\prime} \mathrm{d}, J=8.1\right), 3.85\left(7 \mathrm{OCH}_{3} \mathrm{~s}\right), 3.89\left(4 \mathrm{OCH}_{3}{ }^{\prime} \mathrm{s}\right),{ }^{13} \mathrm{C}-\mathrm{NMR}\left(\mathrm{CDCl}_{3}\right) \delta: 150.2$ 
(C-2), 123.1 (C-3), 181.3 (C-4), 123.8 (C-5), 122.8 (C-6), 131.8 (C-7), 122.5 (C-8), 159.6 (C-9), 106.1 (C-10), $123.6\left(\mathrm{C}-1^{\prime}\right), 121\left(\mathrm{C}-2^{\prime}\right), 122\left(\mathrm{C}-3^{\prime}\right), 131.1\left(\mathrm{C}-4^{\prime}\right), 122\left(\mathrm{C}-5^{\prime}\right), 121\left(\mathrm{C}-6^{\prime}\right), 61.2$ $\left(4 \mathrm{OCH}_{3}{ }^{\prime}\right) 61.3\left(8-\mathrm{OCH}_{3}\right)$; EI-MS $m / z$ 282. The above physical and spectral data are in complete agreement with the data reported in literature for compound 5 [37].

5,3',3-trihydroxy-7,4'-dimethoxyflavanone (6): colorless solid. UV $\lambda_{\max }\left(\mathrm{CH}_{3} \mathrm{Cl}\right) 260,388$ nm. IR(KBr) cm ${ }^{-1}: 1605,1680,3410,1340 ;{ }^{1} \mathrm{H}-\mathrm{NMR}\left(\mathrm{CDCl}_{3}, 400 \mathrm{MHz}\right) \delta: 4.59(2 \mathrm{H} \mathrm{d}$, $J=11.5 \mathrm{~Hz}), 5.04(3 \mathrm{H} \mathrm{d}, J=11.5 \mathrm{~Hz}), 11.24(5 \mathrm{H} \mathrm{s}) 6.19(6 \mathrm{H} \mathrm{d}, J=2.8), 6.18(8 \mathrm{H} \mathrm{d}, J=2.8)$, $6.96\left(2 \mathrm{H}^{\prime} \mathrm{d}, J=2.8\right), 6.91\left(5 \mathrm{H}^{\prime} \mathrm{d}, J=7.8\right), 7.09\left(6 \mathrm{H}^{\prime} \mathrm{d}, \mathrm{d} J=7.8,2.8\right), 3.81\left(7 \mathrm{OCH}_{3} \mathrm{~s},\right), 3.89$ $\left(4 \mathrm{OCH}_{3}{ }^{\prime} \mathrm{s}\right) ;{ }^{13} \mathrm{C}-\mathrm{NMR}\left(\mathrm{CDCl}_{3}\right)$ 8: $85.6(\mathrm{C}-2), 77.4(\mathrm{C}-3), 194.9(\mathrm{C}-4), 166.6(\mathrm{C}-5), 99.1(\mathrm{C}-6)$, 167.8 (C-7), 98.7 (C-8), 168.9 (C-9), 100.2 (C-10), 128.8 (C-1'), 109.1 (C-2'), 144.5 (C-3'), 145.6 $\left(\mathrm{C}-4^{\prime}\right), 115.6\left(\mathrm{C}-5^{\prime}\right), 122.1\left(\mathrm{C}-6^{\prime}\right), 56.8\left(4 \mathrm{OCH}_{3}{ }^{\prime}\right) 56.9\left(8-\mathrm{OCH}_{3}\right)$; EI-MS $m / z$ 360. The above physical and spectral data coincided with the data reported in literature for compound 6 [38].

5',7,8-trihydroxy-6,3', $4^{\prime}$-trimethoxyflavanone (7): colorless solid. UV $\lambda_{\max }\left(\mathrm{CH}_{3} \mathrm{Cl}\right) 250,330$ nm. IR(KBr) cm ${ }^{-1}: 1603,1695,3310,1350 ;{ }^{1} \mathrm{H}-\mathrm{NMR}\left(\mathrm{CDCl}_{3}, 400 \mathrm{MHz}\right) \delta: 8.35(2 \mathrm{H} \mathrm{s}, 6.71(5 \mathrm{H}$ s), $3.89\left(3 \mathrm{OCH}_{3}{ }^{\prime} \mathrm{s}\right), 3.78\left(4 \mathrm{OCH}_{3}{ }^{\prime} \mathrm{s}\right), 7.47\left(6 \mathrm{H}^{\prime} \mathrm{d}, J=2.9\right), 3.47\left(6 \mathrm{OCH}_{3} \mathrm{~s}\right) ;{ }^{13} \mathrm{C}-\mathrm{NMR}\left(\mathrm{CDCl}_{3}\right)$ ঠ: 156.3 (C-2), 123.8 (C-3), 185.6(C-4), 118.1 (C-5), 154.9 (C-6), 151.1 (C-7), 136.6 (C-8), 159.8 (C-9), 107.1 (C-10), $124.8\left(\mathrm{C}-1^{\prime}\right), 124.4\left(\mathrm{C}-2^{\prime}\right), 149.1\left(\mathrm{C}-3^{\prime}\right), 149.9\left(\mathrm{C}-4^{\prime}\right), 136.8\left(\mathrm{C}-5^{\prime}\right), 136.4$ $\left(\mathrm{C}-6^{\prime}\right), 60.9\left(3 \mathrm{OCH}_{3}{ }^{\prime}\right), 59.1\left(4-\mathrm{OCH}_{3}{ }^{\prime}\right) 58.1\left(6-\mathrm{OCH}_{3}\right) ; \mathrm{EI}-\mathrm{MS} \mathrm{m} / z$ 332. The above physical and spectral data are similar with the data reported in literature for compound 7 [39].

\subsection{Docking Analysis Protocol}

The molecular docking studies of all seven compounds (compounds 1-7) were carried out to investigate the putative binding interaction within the target proteins. The starting three-dimensional (3D) structure of $S$. aureus tyrosyl-tRNA synthetase (PDB id: 1JIJ) and topoisomerase II DNA gyrase (PDB id: 2XCT) and beta-hydroxyacyl-ACP dehydratase HadAB (PDB id: 4RLT) were obtained from the Protein Data Bank (PDB) [40]. Ligand molecules were sketched using the Chem Draw Professional v17 (PerkinElmer, Akron, $\mathrm{OH}, \mathrm{USA}$ ). The molecules were converted into 3D using Chem3D (PerkinElmer, Akron, OH, USA) [41]. Before performing the docking protocol, chemically correct models of the ligands were generated using the OMEGA module of OpenEye Scientific Software, and the receptor structures were prepared using the MAKERECEPTOR Wizard Module of Openeye Scientific Software (Santa Fe, NM, USA) [42]. Molecular docking was carried out using the FRED ligand-docking module. FRED requires a set of input conformers for each compound. The conformers of each ligand were generated by OMEGA 3.0.0 (Santa Fe, NM, USA) [43]. Default settings of OMEGA were used for the generation of multi-conformers. Receptor grids were generated using the PDB2Receptor grid generation module. Grids were generated for the prepared proteins. For the $S$. aureus gyrase complex, the grid was generated around ciprofloxacin, while for the $S$. aureus tyrosyl-tRNA synthetase complex, the grid was generated around co-crystal SB-239629 ligand. Moreover, in the case of betahydroxyacyl-ACP dehydratase HadAB grid box was selected around Fisetin. In the case of S. cerevisiae co-crystallized, the grid was generated around co-crystal fluconazole ligand. The boundary box was set at default value, which was spacious enough to encompass the binding regions in target proteins. The docking protocol was optimized using the redocking of the co-crystal ligand within the active site of the target protein. FRED generated ten poses for each ligand and the pose with the lowest Chemguass 4 was selected for further analysis. Binding interactions of best-docked poses were visualized using Discovery Studio client v16.1.0 [44].

\section{Conclusions}

The present work concluded the bioassay's guided phytochemical investigations of Onosma chitralicum, the most active fraction against different microbes was the ethyl acetate fraction with inhibition zone of $16.0 \pm 0.47 \mathrm{~mm}$ against $S$. typhi. The fraction was also active against fungal strains $A$. flavus and $F$. solani with inhibition zones of $60 \pm 0.94 \mathrm{~mm}$ 
and $57 \pm 0.51 \mathrm{~mm}$, respectively. The isolation from ethyl acetate soluble fraction resulted in seven compounds, $\mathbf{1}$ to 7 , as potential pharmaceutical targets. Compounds $\mathbf{1}\left(4^{\prime}, 8-\right.$ dimethoxy-7-hydroxyisoflavone), 6 (5,3',3-trihydroxy-7,4'-dimethoxyflavanone), and 7 $\left(5^{\prime}, 7,8\right.$-trihydroxy-6, $3^{\prime}, 4^{\prime}$-trimethoxyflavanone) were found to be more active against $S$. aureus and S. typhi. Compound 1 inhibit S. typhi and S. aureus to $10 \pm 0.21 \mathrm{~mm}$ and $10 \pm 0.45 \mathrm{~mm}$, whereas compound 6 showed inhibition to $10 \pm 0.77 \mathrm{~mm}$ and $9 \pm 0.20 \mathrm{~mm}$, respectively, and compound 7 inhibit $S$. aureus to $6 \pm 0.36 \mathrm{~mm}$. Docking studies also support the antibacterial activity by binding to bacterial enzymes beta-hydroxyacyl dehydratase (HadAB complex) and tyrosyl-tRNA synthetase. Compound 7 also showed best docking results to the antifungal fluconazole binding enzyme Lanosterol $14 \alpha$-demethylase. These findings lead to the identification of chemical scaffolds, which can lead to new broadspectrum antimicrobial drugs targeted against functionally important proteins of human pathogens, and modification to existing inhibitors of these important proteins to improve affinity and potency. However, a further study (in vivo) would help in supporting further insight into the pharmacological properties of these isolated compounds.

\section{Future Perspectives}

Molecular docking studies give us putative information about the target of interest. Shading light on the antibacterial and antifungal activities, we performed molecular docking to gain insight into the putative binding interaction with possible target protein. In future studies, we will aim to screen these selected compounds against the best-identified target protein.

Author Contributions: Conceptualization, I.A., A.A., and R.U.; data curation, F., I.A., and R.U.; formal analysis, S.U.K., F., and S.A.K.; funding acquisition, R.U. and A.A.; investigation, S.A.K., N.U., A.A., and F.; methodology, N.U. and A.A.; software, M.S.; validation; R.U., M.S., and I.A.; supervision, I.A. and A.A. writing - original draft, S.U.K., S.A.K., F., and N.U.; writing—review and editing, A.A., S.U.K., and I.A. All authors have read and agreed to the published version of the manuscript.

Funding: This research was funded by Princess Nourah bint Abdulrahman University through the Fast-Track Research. Riyadh Saudi Arabia.

Institutional Review Board Statement: Not Applicable.

Informed Consent Statement: Not Applicable.

Data Availability Statement: The data presented in this study are available on request from the corresponding author.

Acknowledgments: The authors extend their appreciation to the Deanship of Scientific Research at Princess Nourah bint Abdulrahman University for funding this work through the Fast-Track Research Funding Program.

Conflicts of Interest: The authors declare no conflict of interest.

Sample Availability: Samples of the compounds are available and can be obtained from authors S.A.K. and I.A.

\section{References}

1. Abeysinghe, P.D. Antibacterial activity of aqueous and ethanol extracts of mangrove species collected from Southern Sri Lanka. Asian J. Pharm. Biol. Res. 2012, 2, 79-83.

2. Mahesh, B.; Satish, S. Antimicrobial activity of some important medicinal plant against plant and human pathogens. World J. Agric. Sci. 2008, 4, 839-843.

3. Walter, C.; Shinwari, Z.K.; Afzal, I.; Malik, R.N. Antibacterial activity in herbal products used in Pakistan. Pak. J. Bot. 2011, 43, 155-162.

4. Imtiaz, B.; Waheed, A.; Rehman, A.; Ullah, H.; Iqbal, H.; Wahab, A.; Almas, M.; Ahmad, I. Antimicrobial Activity of Malva Neglecta and Nasturtium Microphyllum. Int. J. Res. Ayurveda Pharm. 2012, 3, 808-810.

5. Ozgen, U.; Ikbal, M.; Hacimuftuoglu, A.; Houghton, P.; Gocer, F.; Dogan, H.; Coskun, M. Fibroblast growth stimulation by extracts and compounds of Onosma argentatum roots. J. Ethnopharmacol. 2006, 104, 100-103. [CrossRef] [PubMed] 
6. Ijaz, A.; Itrat, A.; Abdul, M.; Sarfraz, A.N.; Muhammad, I.C. Cholinesterase Inhibitory Constituents from Onosma hispida. Chem. Pharm. Bull. 2003, 51, 412-414.

7. Khajuria, R.K.; Jain, S.M. Two new napthhoquinones from the roots of Onosma hispidum. Indian J. Chem. 1993, 32, 390-391.

8. Mellidis, A.S.; Papagergiou, V.P. Pyrrolizidine alkaloids of the plant Onosma heterophylla. Chem. Chron. 1988, 17, 67-73.

9. Mellidis, A.S.; Papageorgiou, V.P. Phenolic constituents from Onosma heterophylla. J. Nat. Prod. 1993, 56, 949-952. [CrossRef]

10. Vijayan, K.; Zhang, W.J.; Tsou, C.H. Molecular taxonomy of Camellia (Theaceae) inferred from nrITS sequences. Am. J. Bot. 2009, 96, 1348-1360. [CrossRef]

11. Heim, K.E.; Tagliaferro, A.R.; Bobilya, D.J. Flavonoid antioxidants: Chemistry, metabolism and structure-activity relationships. J. Nutr. Biochem. 2002, 13, 572-584. [CrossRef]

12. Jacob, V.; Hagai, T.; Soliman, K. Structure-activity relationships of flavonoids. Curr. Org. Chem. 2011, 15, 2641-2657. [CrossRef]

13. Chobot, V.; Hadacek, F.; Bachmann, G.; Weckwerth, W.; Kubicova, L. Pro-and antioxidant activity of three selected flavan type flavonoids: Catechin, eriodictyol and taxifolin. Int. J. Mol. Sci. 2016, 17, 1986. [CrossRef] [PubMed]

14. de Queiroz Ferreira, R.; Greco, S.J.; Delarmelina, M.; Weber, K.C. Electrochemical quantification of the structure/antioxidant activity relationship of flavonoids. Electrochim. Acta 2015, 163, 161-166. [CrossRef]

15. Farhadi, F.; Khameneh, B.; Iranshahi, M.; Iranshahy, M. Antibacterial activity of flavonoids and their structure-activity relationship: An update review. Phytother. Res. 2019, 33, 13-40. [CrossRef] [PubMed]

16. Echeverría, J.; Opazo, J.; Mendoza, L.; Urzúa, A.; Wilkens, M. Structure-activity and lipophilicity relationships of selected antibacterial natural flavones and flavanones of Chilean flora. Molecules 2017, 22, 608. [CrossRef]

17. Lim, H.-j.; Nguyen, T.T.H.; Kim, N.M.; Park, J.-S.; Jang, T.-S.; Kim, D. Inhibitory effect of flavonoids against NS2B-NS3 protease of ZIKA virus and their structure activity relationship. Biotechnol. Lett. 2017, 39, 415-421. [CrossRef] [PubMed]

18. Yang, S.; Zhou, J.; Li, D.; Shang, C.; Peng, L.; Pan, S. The structure-antifungal activity relationship of 5, 7-dihydroxyflavonoids against Penicillium italicum. Food Chem. 2017, 224, 26-31. [CrossRef] [PubMed]

19. Stapleton, P.D.; Shah, S.; Hamilton-Miller, J.M.; Hara, Y.; Nagaoka, Y.; Kumagai, A.; Uesato, S.; Taylor, P.W. Anti-Staphylococcus aureus activity and oxacillin resistance modulating capacity of 3-O-acyl-catechins. Int. J. Antimicrob. Agents 2004, 24, 374-380. [CrossRef] [PubMed]

20. Osawa, K.; Yasuda, H.; Maruyama, T.; Morita, H.; Takeya, K.; Itokawa, H. Isoflavanones from the heartwood of Swartzia polyphylla and their antibacterial activity against cariogenic bacteria. Chem. Pharm. Bull. 1992, 40, 2970-2974. [CrossRef]

21. Dong, Y.; Qiu, X.; Shaw, N.; Xu, Y.; Sun, Y.; Li, X.; Li, J.; Rao, Z. Molecular basis for the inhibition of $\beta$-hydroxyacyl-ACP dehydratase HadAB complex from Mycobacterium tuberculosis by flavonoid inhibitors. Protein Cell 2015, 6, 504-517. [CrossRef]

22. Qiu, X.; Janson, C.A.; Smith, W.W.; Green, S.M.; McDevitt, P.; Johanson, K.; Carter, P.; Hibbs, M.; Lewis, C.; Chalker, A. Crystal structure of Staphylococcus aureus tyrosyl-tRNA synthetase in complex with a class of potent and specific inhibitors. Protein Sci. 2001, 10, 2008-2016. [CrossRef] [PubMed]

23. Bax, B.D.; Chan, P.F.; Eggleston, D.S.; Fosberry, A.; Gentry, D.R.; Gorrec, F.; Giordano, I.; Hann, M.M.; Hennessy, A.; Hibbs, M. Type IIA topoisomerase inhibition by a new class of antibacterial agents. Nature 2010, 466, 935-940. [CrossRef]

24. Sagatova, A.A.; Keniya, M.V.; Wilson, R.K.; Monk, B.C.; Tyndall, J.D. Structural insights into binding of the antifungal drug fluconazole to Saccharomyces cerevisiae lanosterol 14 $\alpha$-demethylase. Antimicrob. Agents Chemother. 2015, 59, 4982-4989. [CrossRef] [PubMed]

25. Kumar, V.; Sharma, A.; Pratap, S.; Kumar, P. Characterization of isoflavonoids as inhibitors of $\beta$-hydroxyacyl-acyl carrier protein dehydratase (FabZ) from Moraxella catarrhalis: Kinetics, spectroscopic, thermodynamics and in silico studies. Biochim. Biophys. Acta BBA Gen. Subj. 2018, 1862, 726-744. [CrossRef]

26. Kimber, M.S.; Martin, F.; Lu, Y.; Houston, S.; Vedadi, M.; Dharamsi, A.; Fiebig, K.M.; Schmid, M.; Rock, C.O. The structure of (3R)-hydroxyacyl-acyl carrier protein dehydratase (FabZ) from Pseudomonas aeruginosa. J. Biol. Chem. 2004, 279, 52593-52602. [CrossRef]

27. Zhang, L.; Liu, W.; Hu, T.; Du, L.; Luo, C.; Chen, K.; Shen, X.; Jiang, H. Structural basis for catalytic and inhibitory mechanisms of $\beta$-hydroxyacyl-acyl carrier protein dehydratase (FabZ). J. Biol. Chem. 2008, 283, 5370-5379. [CrossRef] [PubMed]

28. Sahu, B.D.; Kalvala, A.K.; Koneru, M.; Kumar, J.M.; Kuncha, M.; Rachamalla, S.S.; Sistla, R. Ameliorative effect of fisetin on cisplatin-induced nephrotoxicity in rats via modulation of NF-KB activation and antioxidant defence. PLoS ONE 2014, 9 , e105070. [CrossRef]

29. Pettersen, E.F.; Goddard, T.D.; Huang, C.C.; Couch, G.S.; Greenblatt, D.M.; Meng, E.C.; Ferrin, T.E. UCSF Chimera-A visualization system for exploratory research and analysis. J. Comput. Chem. 2004, 25, 1605-1612. [CrossRef]

30. DeLano, W.L. Pymol: An open-source molecular graphics tool. CCP4 Newsl. Protein Crystallogr. 2002, 40, 82-92.

31. Rehman, A.; Rehman, A.; Ahmad, I. Antibacterial, antifungal, and insecticidal potentials of Oxalis corniculata and its isolated compounds. Int. J. Anal. Chem. 2015, 2015, 842468. [CrossRef] [PubMed]

32. Khan, A.M.; Qureshi, R.A.; Gilani, S.A.; Ullah, F. Antimicrobial activity of selected medicinal plants of Margalla hills, Islamabad, Pakistan. J. Med. Plants Res. 2011, 5, 4665-4670.

33. Ma, X.; Wang, L.; Guo, Y.; Guo, S. A new isoflavone from Huoxue Yiqi Tang. Zhongguo Zhong Yao Za Zhi Zhongguo Zhongyao Zazhi China J. Chin. Mater. Med. 2005, 30, 1159-1162.

34. Li, X.; Li, J.; Wang, D.; Wang, W.; Cui, Z. Chromone and flavonoids from Maackia amurensis. Asian J. Tradit. Med. 2009, 4, 98-103. 
35. Zeng, J.-F.; Wei, H.-X.; Li, G.-L.; Zhu, D.-Y. Three prenylated isoflavans from Maackia tenuifolia. Phytochemistry 1998, $47,903-905$. [CrossRef]

36. Li, J.; Cui, Z.; Zhang, F. Research progess in the chemical constituents and pharmacological activities of Maackia species. J. Shenyang Pharm. Univ. 2006, 23, 541-545.

37. Wu, T.-S.; Hsu, M.-Y.; Kuo, P.-C.; Sreenivasulu, B.; Damu, A.G.; Su, C.-R.; Li, C.-Y.; Chang, H.-C. Constituents from the Leaves of Phellodendron a murense var. w ilsonii and Their Bioactivity. J. Nat. Prod. 2003, 66, 1207-1211. [CrossRef] [PubMed]

38. Zeng, J.; Zhu, D. Chemical constituents of the roots of Maackia tenuifolia (Leguminosae). Acta Bot. Sin. 1999, 41, $997-1001$.

39. Rossi, M.H.; Yoshida, M.; Maia, J.G.S. Neolignans, styrylpyrones and flavonoids from an Aniba species. Phytochemistry 1997, 45, 1263-1269. [CrossRef]

40. Berman, H.M.; Westbrook, J.; Feng, Z.; Gilliland, G.; Bhat, T.N.; Weissig, H.; Shindyalov, I.N.; Bourne, P.E. The protein data bank. Nucleic Acids Res. 2000, 28, 235-242. [CrossRef]

41. Elmer, P. Chem Bio Draw Profeesional Version (15.0. 0.106); Cambridge Soft: Waltham, MA, USA, 2017.

42. OMEGA. OpenEye Scientific Software; OMEGA: Santa Fe, NM, USA, 2013.

43. FRED. OpenEye Scientific Software, Toolkit, OEChem; FRED: Santa Fe, NM, USA, 2013.

44. BIOVIA. BIOVIA Discovery Studio Visualizer, v16. 1.0. 15350; BIOVIA: San Diego, CA, USA, 2015. 